\title{
PSIKODINAMIKA FRAUDSTER DALAM SUDUT PANDANG ILMU PSIKIATRI
}

\author{
Hafid Algristian $^{1}$, Hanafi Muljohardjono ${ }^{2}$ \\ ${ }^{1}$ Fakultas Kedokteran Universitas Nahdlatul Ulama Surabaya \\ ${ }^{2}$ Fakultas Kedokteran Universitas Airlangga Surabaya \\ e-mail:
}

\begin{abstract}
Abstrak: Fraudster atau pelaku fraud diindikasikan sebagai seseorang dengan kepribadian narsisistikantisosial. Pada beberapa kasus justru dilakukan oleh orang tanpa gangguan psikiatrik apa pun, asal memenuhi tiga unsur dalam fraud. Fraud adalah tindakan curang yang tidak selalu bertujuan menguntungkan diri sendiri, melainkan untuk merugikan pihak lain. Literatur review ini ditulis untuk mengkaji psikodinamika fraudster dalam sudut pandang ilmu psikiatri, sehingga pengambil kebijakan dapat menentukan langkah penanggulangan fraud mulai dari asesmen sumber daya manusia hingga tata laksana. Tata laksana holistis fraud mencakup aspek psikobiologi, personality, dan psikososiospiritual.
\end{abstract}

Kata kunci: fraud, narsisistik, antisosial, malingering

\section{PENDAHULUAN}

Fraud dapat diartikan sebagai penipuan atau kecurangan, menyebabkan kerugian materiil maupun imateriil yang sangat besar di institusi mana pun. Pelaku fraud tidak terbatas pada mereka yang terdesak secara sosial-ekonomi, namun juga pada mereka yang memiliki status sosial, jabatan, atau keahlian tertentu. Mereka mampu "mengakali" sistem hingga menguntungkan dirinya atau kelompoknya. Pelaku kemudian melakukan undoing atau "penebusan dosa", di mana ia akan memberikan hadiah atau menjamu orang lain secara berlebihan, atau "disedekahkan" kepada kaum dhuafa, untuk menutupi kecurangan mereka. Hasilnya, image sosial mereka tetap terselamatkan (Wilhelm, 2004; Kayo, 2013; Wind, 2014).

Pada beberapa kasus yang dilaporkan melalui media, menunjukkan bahwa para fraudsters memiliki latar belakang psikodinamika yang menarik untuk dikaji. Makalah ini dimaksudkan untuk memberikan gambaran mengenai sudut pandang psikiatri pada fraudsters. Dengan me- ngenali aspek psikiatri ini, dapat direncanakan sebuah tata laksana holistis dan komprehensif pada fraudsters. Holistis yang dimaksud adalah tata laksana menyeluruh pada aspek biopsikososiospiritual, sementara komprehensif adalah dengan melibatkan stakeholder yang terkait dengan kasus tersebut (Wilhelm, 2004; Wallang \& Taylor, 2012; Fitrawansyah, 2014).

\section{UNSUR PERBUATAN FRAUD}

Sesuai Pedoman Chartered Global Management Accountant (CGMA), fraud haruslah memenuhi tiga unsur berikut ini: (1) tindakan yang disengaja; (2) kecurangan; (3) menimbulkan keuntungan pribadi/kelompok atau kerugian di pihak lain. Misalnya mahasiswa yang melakukan titip absensi ketika kuliah pagi, apakah termasuk fraud? Maka perlu dikaji berdasarkan pertanyaan berikut. Apakah titip absensi adalah tindakan yang disengaja? YA. Apakah titip absensi tergolong curang? YA. Apakah titip absensi menguntungkan diri sendiri/kelompok? YA. Tanpa 
melihat ukuran keuntungan dan kerugiannya asalkan ketiga unsur itu terpenuhi, maka ia termasuk tindakan fraud (Lees, 2012; Kayo, 2013; Fitrawansyah, 2014; Wind, 2014).

\section{TEORI FRAUD}

Cressey (1953) melakukan penelitian terhadap 200 orang narapidana di Midwest, menyimpulkan bahwa etiologi fraud adalah apa yang disebutnya sebagai Fraud Triangle, yaitu "Pressure, Opportunity, and Rationalization". Yakni adanya tekanan (pressure) atau konflik kepentingan (conflict of interest), adanya kesempatan untuk melakukan (opportunity), dan adanya kecenderungan untuk mencari pembenaran terhadap perilakunya (rationalization) (Wallang \& Taylor, 2012; Kayo, 2013; Sizemore, 2013; Fitrawansyah, 2014).

Martin T. Biegelman (2006) meneliti tentang perilaku korupsi, menyebutkan bahwa terjadinya fraud ternyata memenuhi formula $\mathrm{C}=\mathrm{P}-\mathrm{A}$, di mana korupsi (corruption, C) akan terjadi jika kekuasaan (power, P) diselenggarakan tanpa pertanggungjawaban yang semestinya (accountability, A). Dengan kata lain, ada abuse of power. Melalui kekuasaan yang dimiliki, seseorang bisa menciptakan peluang (opportunity) terjadinya fraud, dan melegalkan alasan-alasan yang berakibat "memaksakan hukum agar sesuai dengan kemauannya" (rasionalisasi). Di balik itu semua, sebenarnya setiap pelaku penyalahgunaan kekuasaan ternyata memiliki rasa tertekan (pressure) tertentu yang mendorongnya melakukan rasionalisasi dan menciptakan peluang terjadinya fraud. Inilah yang disebut The Power Theory (Collier \& Vicente, 2012; Wallang \& Taylor, 2012; Kayo, 2013).

\section{PSIKODINAMIKA FRAUDSTER}

\section{Tekanan (pressure)}

Hendaknya perlu dibedakan antara perilaku antisosial (antisocial behavior) dan gangguan

Tabel 1 Contoh Gangguan Psikiatrik yang Melatarbelakangi Kejadian Fraud (Wallang \& Taylor, 2012)

\begin{tabular}{|c|c|c|}
\hline ICD-10/DSM-IV diagnosis & $\begin{array}{l}\text { Level of fraudulent } \\
\text { crime }\end{array}$ & $\begin{array}{l}\text { Types of crime types where } \\
\text { pathology may be present }\end{array}$ \\
\hline $\begin{array}{l}\text { - Personality disorders: } \\
\text { psychopathic/callous unemotional } \\
\text { traits, narcissistic } \\
\text { - Malingering }\end{array}$ & $\begin{array}{l}\text { - Sophisticated/ } \\
\text { - complex, organized }\end{array}$ & $\begin{array}{l}\text { - Ponzi schemes } \\
\text { - Complex corporate fraud (Enron, } \\
\text { Anderson) } \\
\text { - West African advance fee 'scams' } \\
\text { - Pyramid schemes }\end{array}$ \\
\hline $\begin{array}{l}\text { - Stress-related disorder } \\
\text { - Depression } \\
\text { - Antisocial personality disorder }\end{array}$ & $\begin{array}{l}\text { - Mid-levell } \\
\text { - semi-organized }\end{array}$ & $\begin{array}{l}\text { - Inappropriate use of funds } \\
\text { - Diversion of liquid assets } \\
\text { (embezzlement) } \\
\text { - Misappropriation } \\
\text { - Deception } \\
\text { - Internet fraud }\end{array}$ \\
\hline $\begin{array}{l}\text { - Learning (intellectual) disability } \\
\text { (mild/borderline) } \\
\text { - Psychosis (mania) } \\
\text { - Substance misuse } \\
\text { - Antisocial personality disorder }\end{array}$ & $\begin{array}{l}\text { - Low/opportunistic, } \\
\text { - minimal complexity }\end{array}$ & $\begin{array}{l}\text { - Credit card fraud } \\
\text { - Aliases } \\
\text { - Benefit fraud }\end{array}$ \\
\hline
\end{tabular}


kepribadian antisosial (antisocial personality disorder-ASPD). Seseorang dapat melakukan perbuatan melanggar hukum (antisosial) tanpa harus memiliki kepribadian antisosial. Perilaku ini muncul sebagai reaksi terhadap tekanan dari sekitarnya, konflik neurotik (cemas dan depresi), atau pola pikir psikotik (waham dan halusinasi). Pada umumnya faktor pressure terdiri dari keadaan-keadaan yang bersifat force de majeur, artinya di luar kehendak fraudsters (Gabbard, 2005; Wallang \& Taylor, 2012).

Tekanan (pressure) yang dialami fraudsters dapat berupa faktor sosioekonomi atau faktor psikobiologis. Multiaksial diagnosis dalam ilmu psikiatri menyatakan faktor sosioekonomi bersesuaian dengan apa yang ada dalam Axis IV, sementara faktor psikobiologis sesuai dengan Axis I atau III. Dengan berkonsultasi kepada psikiater untuk melihat dua faktor ini, pengambil kebijakan akan memiliki pandangan holistis dalam mengkaji perbuatan fraudsters (Balafoutas et al., 2011; Wallang \& Taylor, 2012).

\section{Kesempatan}

Salah satu yang mendukung terjadinya frand adalah adanya kesempatan bagi pelaku untuk melaksanakan aksinya. Kesempatan ini dapat tersedia dikarenakan sistem pengawasan yang lemah, dapat juga dimanipulasi sendiri oleh pelaku. Tidak dipungkiri, memperketat sistem pengawasan adalah jalan paling utama yang bisa ditempuh untuk mencegah fraud. Di sisi lain, terdapat istilah affinity fraud, yakni fraud yang terjadi pada sebuah kelompok atau komunitas. Mereka memiliki keterikatan atau kesamaan, seperti kelompok keagamaan, fansub, kelompok hobi, persatuan pelajar, ikatan profesi tertentu seperti advokat, dokter, dan semacamnya. Mereka toleran dan permisif satu sama lain, sehingga terbuka kesempatan untuk mengeksploitasi kepercayaan, kecurangan, bahkan menipu antaranggota (Perri \& Brody, 2011, 2012; Kayo, 2013; Sizemore, 2013; Alanezi \& Brooks, 2014).

\section{Rasionalisasi}

Rasionalisasi yang dimaksud di sini bukanlah coping strategy untuk menghadapi stressor, melainkan perilaku fraudster yang berusaha mencari pembenaran atas perbuatannya. Proses berpikir fraudster sering terdapat cognitive dissonance, atau kejanggalan kognisi sehingga dalam kondisi berbeda, ia bersikap berbeda. Fraudster selalu bisa menjelaskan mengapa melakukan hal itu, dan menjadi sangat teguh terhadap pendiriannya tanpa memperhatikan bahwa pendirian tersebut tidak mendapat tempat dalam etika sosialnya (Wallang \& Taylor, 2012).

Salah satu contoh ekstrem cognitive dissonance adalah pathological lying atau bohong patologis. Disebut dalam istilah psikiatrik klasik sebagai pseudologia fantastica; terjemahan bebasnya adalah logika palsu yang menakjubkan. Pelaku memiliki kemampuan untuk membuat sandiwara di mana ia berperan sebagai orang lain untuk melakukan serangkaian kasus fraud. Pseudologia memiliki dua ciri khas yakni melibatkan identitas menyeluruh dari seseorang, dan tanpa adanya motivasi eksternal. Pelaku-dalam hal ini mungkin disebut sebagai penderita, benarbenar mengubah identitas pribadinya (misalnya sebagai polisi atau dokter) dan berperan sebagai sosok yang ia pilih (Wallang \& Taylor, 2012).

Beberapa praktisi hukum tidak menyetujui jika pseudologia dapat dijadikan alasan untuk memperingan hukuman. Kemampuan intelektual mereka masih intak sehingga dianggap mampu bertanggung jawab. Beberapa praktisi lain menganggap sebaliknya, bahwa pseudologia adalah 
kondisi sakit seperti waham pada skizofrenia atau gangguan waham menetap, sehingga perilaku fraud-nya adalah bagian dari sakitnya. Dibandingkan dengan bohong non-patologis (common lie), penderita pseudologia tidak memiliki motivasi eksternal apapun. Psikiater akan curiga pada diagnosis pseudologia bila pelaku tidak memiliki motivasi yang jelas terkait perilaku fraud-nya. Keadaan ini sangat berbeda dengan kepribadian antisosial yang mensyaratkan keuntungan pribadi atau kerugian orang lain (Wallang \& Taylor, 2012).

\section{Kepribadian Antisosial}

Dari tabel 1 dapat dilihat bahwa kepribadian antisosial tidak terbatas pada satu tingkat intelejensi, justru semakin tinggi tingkat intelejensinya, semakin berbahaya perbuatan fraudnya. Mereka dengan antisocial personality disorder (ASPD) mengalami "superego lacunae", yakni superegonya tidak memiliki kendali optimal terhadap perilaku agar sesuai etika sosialnya (social fitness). Superego lacunae ini dapat disebabkan pola asuh pada anak di usia 3-5 tahun. "Ke-aku-an" anak sangat menonjol, mulai memiliki sense of belonging dan tidak mau kalah. Orang tua yang otoriter-dominan membentuk coping proyeksi dan displacement anak terhadap dunia sekitarnya saat dewasa. Orang tua yang permisif-submisif, tidak mampu memangkas keaku-an anak yang besar, sehingga mencetak anak sebagai sosok manja (spoiled child). Kedua pola asuh ini tidak melatihkan empati anak terhadap sekitarnya, menjadikannya lebih narisistik-sadistik, sehingga mendukung terbentuknya ASPD (Hall \& Lindzey, 1993; Millon \& Davis, 2000; Pervin, 2003; Gabbard, 2005; Barnes\& Jacobs, 2013; Gerhart et al, 2013; Smith et al, 2013).

\section{Perilaku Sadistik}

Sebagian fraudtser merasakan kenikmatan tersendiri jika menyaksikan korbannya menderita karena perbuatannya. Tingkat kompleksitas kasus fraud sebenarnya hanya untuk memuaskan pelaku dan sebagai pembuktian bahwa mereka mampu melakukan hal-hal yang tidak mungkin. Adanya sensasi emosional adalah imbalan yang lebih tinggi dibandingkan harta yang mereka dapatkan. Semakin kompleks kasusnya, semakin mereka puas. Pada analisis five-factors model, pelaku umumnya memiliki skala agreeableness (empati) dan neuroticism (kecemasan) yang rendah (Nettle, 2007; Pervin, 2003; Wallang \& Taylor, 2012).

\section{Asesmen Kepribadian Antisosial}

Hare Psychopaty Checklist-Revised (PCL$\mathrm{R})$ adalah instrumen untuk membantu melakukan asesmen terhadap ciri kepribadian antisosial. Instrumen ini memiliki dua faktor dan masingmasing faktor terdiri dari dua faset. Faktor-1 yang menggambarkan ciri kepribadian narsisistik, terdiri dari faset interpersonal dan faset afektif. Sementara faktor-2 menggambarkan perilaku antisosial, dengan faset gaya hidup dan faset antisosial itu sendiri. Instrumen menggambarkan kondisi kognitif, afektif, dan psikomotor dengan kecenderungan psikopatik atau tidak. Selain itu, dapat digunakan instrumen B-Scan untuk mendeteksi potensi fraud dalam perusahaan (Cooke \& Miche, 1997; Hare et al., 1990; Mathieu et al., 2012; Neumann et al., 2013).

\section{Waspada Malingering}

Pada berbagai macam kasus, malingered mental disorder hampir selalu menampakkan dua gejala utama, yakni (1) Melibatkan kombi- 
nasi gejala psikiatrik yang tidak khas (atypical combination of symptoms) dan (2) Adanya hambatan kognitif sehingga menimbulkan score yang rendah pada tes IQ atau tes kognitif tertentu. Mendeteksi perilaku malingering atau berpurapura memang tidak mudah. Penggunaan tes seperti Test of Memory Malingering (TOMM; Tombaugh, 1997) dan Miller-Forensic Assessment of Symptoms Test (M-FAST; Jackson, 2005) dapat cukup membantu (Wallang \& Taylor, 2012).

\section{TATA LAKSANA PSIKIATRIK HOLISTIS}

Setelah mendapat putusan persidangan, psikiater dapat mengajukan usulan tata laksana yang holistis untuk pelaku fraud. Pada prinsipnya, tata laksana ini sama dengan tata laksana kasus psikiatrik lainnya, yakni 3P-aspects, psychobiology, personality, dan psychosociospiritual. (Basrowi \& Susilo, 2006; Wallang \& Taylor, 2012).

\section{Tatalaksana Psikobiologis}

Pada level kompleksitas kasus fraud yang sederhana (level ringan dan sedang), di mana latar belakang pelaku adalah mengalami gejala depresi, manik-psikotik, gangguan waham, gangguan pengendalian impuls, gangguan intelektual, termasuk gangguan penyesuaian akibat masalah psikososial, dapat diberikan medikamentosa sebagaimana kasus psikiatrik pada umumnya. Perbedaan mendasar pada tata laksana kasus fraud adalah kebutuhan untuk menghambat reseptor dopaminergik, sehingga menurunkan agresivitas dan kecermelangan daya berpikir pelaku (sophisticated train of thought). Salah satu pilihan psikofarmaka adalah antipsikotik atipikal, seperti venlafaxine (Gerhart et al, 2013; Wallang \& Taylor, 2012).

\section{Tata Laksana Faktor Kepribadian}

Tata laksana untuk faktor ini melibatkan tiga area, yakni area kultural, area kelompok/ komunitas, dan area individu. Salah satu sanksi yang berkembang di tanah air adalah adanya sanksi adat, mulai dari yang paling ringan yakni dikucilkan/diasingkan, dicibir, hingga hukumanhukuman fisik. Beberapa sanksi adat mampu menunjukkan behavioral approach yakni membuat sikap antisosial menjadi lebih prososial. Pendekatan ini kemudian diakomodasi dalam hukum dan perundang-undangan, sebagaimana istilah di Kanada dan Amerika yakni altruistic punishment. Syarat hukuman ini adalah dengan berkontribusi positif untuk lingkungan sosialnya, seperti membayar denda dan melakukan kegiatan kemanusiaan (Herrmann et al., 2008; Crowtheret et al., 2012; Neumann et al., 2013; Sylwester et al., 2013).

\section{Tata Laksana Psikospiritual}

Salah satu faktor protektif terhadap perilaku dan kepribadian antisosial adalah pendidikan. Pendidikan memberikan peran penting untuk menanamkan nilai moral dan nilai-nilai prososial. Praktisi pendidikan di negara Barat masih sangat antipati untuk mengintegrasikan nilai-nilai spiritualitas dan keagamaan ke dalam pendidikan, dan menganggap bahwa fungsi pendidikan adalah menanamkan nilai-nilai moral yang bersumber dari kearifan lokal. Negaranegara Timur memiliki spiritualitas yang lebih dapat diterima oleh para praktisi pendidikan. Mayoritas pendidikan di Timur menekankan bahwa setiap manusia dianugerahi Tuhan untuk memiliki peran penting dalam merawat alam semesta. Satu titik temu antara Barat dan Timur adalah adanya nilai-nilai moral yang membuat masyarakatnya saling terikat satu sama lain, 
baik yang bersumber dari kearifan lokal maupun Ketuhanan (Basrowi \& Susilo, 2006; Crowther et al, 2012; Carbone-lopez, 2013; Smith et al, 2013).

\section{KESIMPULAN}

Fraud memiliki tiga unsur pokok, yakni tindakan yang disengaja, kecurangan, menimbulkan keuntungan pribadi/kelompok atau kerugian di pihak lain. Teori yang mendasari fraud terdiri dari fraud triangle (pressure, opportunity, dan rationalization) dan the power theory (corruption terjadi jika power dilaksanakan tanpa accountability). Hendaknya perlu dibedakan antara perilaku antisosial dan kepribadian antisosial seorang fraudster. Perilaku antisosial muncul karena tekanan-tekanan baik psikis, biologis, maupun sosioekonomi. Kepribadian antisosial ditandai dengan "ke-aku-an" yang besar dan cenderung sadistik. Tata laksana holistis fraud dari sudut pandang ilmu psikiatri meliputi faktor psikobiologis termasuk penggunaan antipsikotik atipikal, personality seperti terlibat dalam kegiatan sosial, dan psikospiritual melalui pendidikan moral dan agama.

\section{DAFTAR RUJUKAN}

Alanezi, F., \& Brooks, L. 2014. Combatting Online Fraud in Saudi Arabia Using General Deterrence Theory (GDT). Security Awareness \& Management in Developing Economies, 1-13.

Balafoutas, L; Beck, A.; Kerschbamer, R.; Sutter, M. 2011. What Drives Taxi Drivers? A Field Experiment on Fraud in a Market for Credence Goods. Working Papers in Economics and Statistics, No. 2011-11.
Barnes, J.C., \& Jacobs, B.A. 2013. Genetic Risk for Violent Behavior and Environmental Exposure to Disadvantage and Violent Crime: The Case for Gene Environment Interaction. doi:10.1177/ 0886260512448847.

Basrowi, Susilo, S. 2006. Demokrasi dan HAM. Kediri: Jenggala Pustaka Utama

Carbone-lopez, K. 2013. Across Racial/Ethnic Boundaries: Investigating Intimate Violence within a National Sample. doi: $10.1177 / 0886260512448850$.

Collier, P. \& Vicente, P.C. 2012. Violence, Bribery, and Fraud: The Political Economy of Elections in Sub-Saharan Africa. Public Choice, 153, 117-147. doi:10.1007/ s11127-011-9777-z.

Cooke, D. J., \& Michie, C. 1997. An Item Response Theory Analysis of the Hare Psychopathy Checklist-Revised. Psychological Assessment, 9(1), 3-14. doi: 10.1037/1040-3590.9.1.3.

Crowther, S., Goodson, C., Mcguire, J., \& Dickson, J.M. 2013. Having to Fight, Journal of Interpersonal Violence, 28(1), 62-79. doi:10.1177/0886260512448846.

Fitrawansyah. 2014. Fraud \& Auditing. Jakarta: Mitra Wacana Media.

Gabbard, G.O. 2005. Psychodynamic Psychiatry in Clinical Practice. 4th Ed. Washington DC: American Psychiatric Publishing.

Gerhart, J. I., Ronan, G. F., Russ, E., \& Seymour, B. 2013. The Moderating Effects of Cluster B Personality Traits on Violence Reduction Training: A Mixed-Model Analysis. Journal of Interpersonal Violence. doi: 10.1177/0886260512448849.

Hall, C.S., Lindzey, G. 1993. Teori-Teori Psikodinamik (Klinis). Yogyakarta: Kanisius. 
Hare, R.D., Harpur, T. J., Hakstian, a.R., Forth, A.E., et al. 1990. The revised Psychopathy Checklist: Reliability and Factor Structure. Psychological Assessment, 2(3), 338341. doi:10.1037/1040-3590.2.3.338.

Herrmann, B., Thöni, C., \& Gächter, S. 2008. Anti-Social Punishment across Societies. SCIENCE, 319(March), 1362-1367.

Kayo, H. Amrizal Sutan. 2013. Audit Forensik: Penggunaan dan Kompetensi Auditor dalam Pemberantasan Tindak Pidana Korupsi. Yogyakarta: Graha Ilmu.

Lees, G. (2012). Fraud Risk Management: A Guide to Good Practice. CGMA Report. New York: American Institute of CPAs.

Mathieu, C., Hare, R.D., Jones, D.N., Babiak, P., \& Neumann, C.S. 2012. Factor Structure of the B-Scan 360: A Measure of Corporate Psychopathy. Psychological Assessment. doi:10.1037/a0029262.

Millon, T., Davis, R. 2000. Personality Disorder in Modern Life. Canada: John Wiley \& Sons.

Nettle, D. 2007. Personality: What Makes The Way You Are. Oxford: Oxford University Press

Neumann, C.S., Uzieblo, K., Crombez, G., \& Hare, R.D. 2013. Understanding the Psychopathic Personality Inventory (PPI) in Terms of the Unidimensionality, Orthogonality, and Construct Validity of PPI-I and -II. Personality Disorders, 4(1), 77-9. doi:10.1037/a0027196.
Perri, F.S., \& Brody, R.G. 2011. Birds of the Same Feather: The Dangers of Affinity Fraud. University of New Mexico, Journal of Forensic Studies in Accounting \& Business,3(1), 33-46.

Perri, F.S., Brody, R.G. 2012. The Optics of Fraud/: Affiliations that Enhance offender Credibility. Journal of Financial Crime. doi:10.1108/13590791211243147

Pervin, L.A. 2003. The Science of Personality. Oxford University Press (Vol. 1). New York: Oxford University Press.

Sizemore, O.J. 2013. The Role of Perpetrator Motivation in Two Crime Scenarios. Journal of Interpersonal Violence. doi:10.1177/ 0886260512448843.

Smith, C.A., Park, A., Ireland, T.O., Elwyn, L., \& Thornberry, T.P. 2013. Long-Term Outcomes of Young Adults Exposed to Maltreatment: The Role of Educational Experiences in Promoting Resilience to Crime and Violence in Early Adulthood. doi: 10.1177/0886260512448845

Wallang, P. \& Taylor, R. 2012. Psychiatric and Psychological Aspects of Fraud Offending. Advances in Psychiatric Treatment. doi: 10.1192/apt.bp.111.008946

Wilhelm, W.K. 2004. The Fraud Management Lifecycle Theory: A Holistic Approach to Fraud Management. Journal of Economic Crime Management. Spring 2004, 2(2).

Wind, A. 2014. Forensic Accounting. Cipayung: Dunia Cerdas. 
Medical and Health Science Journal, Vol. 2, No. 1, February 2018 